\title{
Comparision of Design Codes ACI 318-11, IS 456:2000 and Eurocode II
}

\author{
Iqbal Rasool Dar \\ Student, Al-Falah University, \\ Faridabad, Haryana, India
}

\begin{abstract}
National building codes have been formulated in different countries to lay down guidelines for the design and construction of structures. The codes have been evolved from the collective wisdom of expert structural engineers, gained over the years. These codes are periodically revised to bring them in line with current research, and often current trends.
\end{abstract}

The main function of the design codes is to ensure adequate structural safety, by specifying certain essential minimum reinforcement for design. They render the task of the designer relatively easy and simple, results are often formulated in formulas or charts. The codes ensure a certain degree of consistency among different designers. Finally, they have some legal validity in that they protect the structural designer from any liability due to structural failures that are caused by inadequate supervision and/or faulty material and construction.

The aim of this project is to compare the design codes of IS 456-2007, ACI 318-11 code and Eurocode II. The broad design criteria (like stress strain block parameters, L/D ratio, load combinations, formula will be compared along with the area of steel for the major structural members like beams, slab, columns, footing to get an over view how the codes fair in comparison with each other. The emphasis will be to put the results in tabular and graphical representation so as to get a better clarity and comparative analysis.

\section{INTRODUCTION}

Structural design is the methodical investigation of the stability, strength and rigidity of structures. The basic objective in structural analysis and design is to produce a structure capable of resisting all applied loads without failure during its intended life.
The shear capacity, compression capacity \& moment capacity of a structural member is a fundamental part of the overall analysis required when designing or evaluating an assembly of structural concrete sections.

The aim of the research is to compare broader design criteria of the said three design codes and calculate the area of steel for different structural members using the respective codes for the sake of comparison and subsequent comparative analysis.

A brief about the Design Codes;

- $\quad$ IS 456-2000

This Indian Standard (Fourth Revision) was adopted by the Bureau of Indian Standards, after the draft finalized by the Cement and Concrete Sectional Committee had been approved by the Civil Engineering Division Council.

This standard was first published in 1953 under the title 'Code of practice for plain and reinforced concrete for general building construction' and subsequently revised in 1957. The code was further revised in 1964 and published under modified title 'Code of practice for plain and reinforced concrete', thus enlarging the scope of use of this code to structures other than general building construction also. The third revision was published in 1978, and it included limit state approach to design. This is the fourth revision of the standard. This revision was taken up with a view to keeping abreast with the rapid development in the field of concrete technology and to bring in further modifications/improvements in the light of experience gained while using the earlier version of the standard. 
IS 456-2000 Plain and Reinforced Concrete - Code of Practice is an Indian Standard code of practice for general structural use of plain and reinforced concrete. The latest revision of this standard was done in year 2000 , reaffirmed 2005. This code uses the limit state design approach. It is written for use in India. It gives extensive information on the various aspects of concrete. IS 456 is considered as the Bible for Civil Engineers in India.

\section{- ACI 318}

The American Concrete Institute expects to publishes the ACI 318 updating it regularly to keep the code in sync in contemporary design developments, technological achievements and construction requirements. The process to codify design formulas and other design consideration goes back to 1904 in USA when Charles C. Brown with issue of Municipal Engineering discussed the idea of forming an organization to bring order and standard practices to the industry. The newest version of ACI 318 will be launched in 2019.

\section{- EUROCODE II}

The process of codifying EUROCODE II goes back to 1975 in Treaty Of Rome when European Commission asked CEN (Centre European de Normalisation) to draft structural design standards that could be used across the Common Market. It has been updated several times since then the latest update will be available by 2020 .

\section{AIM AND SCOPE OF PROJECT}

\begin{tabular}{|c|c|c|c|c|}
\hline$\frac{S_{r}}{N_{0}}$ & $\begin{array}{l}\text { Country } \\
\text { Standards }\end{array}$ & $\begin{array}{l}\text { Modulus of } \\
\text { Elasticity }\end{array}$ & $\begin{array}{l}\text { Stress block } \\
\text { parameter for } \\
\text { high grade } \\
\text { concrete }\end{array}$ & $\begin{array}{c}\text { Strain } \\
\text { Distribution } \\
\text { (Deep } \\
\text { Beams) }\end{array}$ \\
\hline 1 & $\begin{array}{l}\text { American } \\
\text { Std. }\end{array}$ & $\mathrm{Ec}=\mathrm{w} 1.50 \mathrm{c} \times 0.043 \sqrt{\mathrm{f}^{\prime} \mathrm{MPa}}$ & Changes & Non Linear \\
\hline 2 & $\begin{array}{l}\text { European } \\
\text { Std. }\end{array}$ & $\mathrm{Ec}^{1 / 1} 422000\left(\mathrm{fc}^{\prime} / 10\right)^{\wedge} 0.3$ & Changes & Non Linear \\
\hline 3 & Indian Std. & 5000 square root of fck & Not considered & Not Considered \\
\hline
\end{tabular}

\section{ELASTIC MODULUD OF CONCRETE}

IS 4562000 doesn't consider stress block parameters for high grade concrete and strain distribution for deep beams, high grade concrete has become very
The crux of this thesis is the comparison of the three prevailing concrete design codes regarding the design and detailing of RCC.

To accomplish this, a series of Excel spreadsheets were created to ensure the accuracy and consistency of all calculations performed; however as programming is not the point of this research several simplifying assumptions were made to reduce the time required to create, vet and utilize these tools.

Both sections focus solely on analytical results; no laboratory experiments were carried out. Comparisons were based on but not limited to maximum predicted allowable load.

The objective of this thesis is to clarify the differences between the two prevailing concrete design codes, ACI 318-05, IS 456, and EUROCODE II and categorize them as 2 major, minor, or insignificant. In cases where other editions are referenced, the edition under discussion shall be noted.

A comprehensive literature review providing coverage of examples illustrating additional differences found between the ACI 318 and IS 456 codes AND EUROCODE II.

\section{DESIGN PROCESS AND RESULTS}

\section{BROADER DESIG N CRITERIAS}

The broad design criteria of AMERICAN CODE (ACI 318), EURO CODE, and IS 456 (2000) are tabulated below to get a contrasted view of

differences among the codes.

common now, even in India, so BIS should consider the above given lacunas to stre- ngthen the design code with current situations. 
International Journal of Trend in Scientific Research and Development (IJTSRD) ISSN: 2456-6470

\begin{tabular}{|l|l|l|l|l|l|}
\hline Sr No & $\begin{array}{l}\text { Country } \\
\text { Standards }\end{array}$ & $\begin{array}{l}\text { Tensile } \\
\text { Strength of } \\
\text { Concrete } \\
\text { (Flexure } \\
\text { Design) }\end{array}$ & $\begin{array}{l}\text { Max } \\
\text { Concrete } \\
\text { strain }\end{array}$ & $\begin{array}{l}\text { Curing } \\
\text { Effect on } \\
\text { concrete } \\
\text { strength }\end{array}$ & $\begin{array}{l}\text { Confined } \\
\text { Concrete } \\
\text { Stress } \\
\text { Strain } \\
\text { Curve }\end{array}$ \\
\hline 1 & $\begin{array}{l}\text { Americn } \\
\text { Std. }\end{array}$ & $\begin{array}{l}\text { Not } \\
\text { considered }\end{array}$ & .003 & $\begin{array}{l}\text { Not } \\
\text { Mentioned }\end{array}$ & $\begin{array}{l}\text { Not } \\
\text { Mentioned }\end{array}$ \\
\hline 2 & $\begin{array}{l}\text { European } \\
\text { Std. }\end{array}$ & $\begin{array}{l}\text { Not } \\
\text { considered }\end{array}$ & .0035 & Mentioned & Mentioned \\
\hline 3 & Indian Std. & $\begin{array}{l}\text { Not } \\
\text { considered }\end{array}$ & .0035 & $\begin{array}{l}\text { Not } \\
\text { Mentioned }\end{array}$ & $\begin{array}{l}\text { Not } \\
\text { Mentioned }\end{array}$ \\
\hline
\end{tabular}

BASIC STRESS STRAIN PARAMETERS

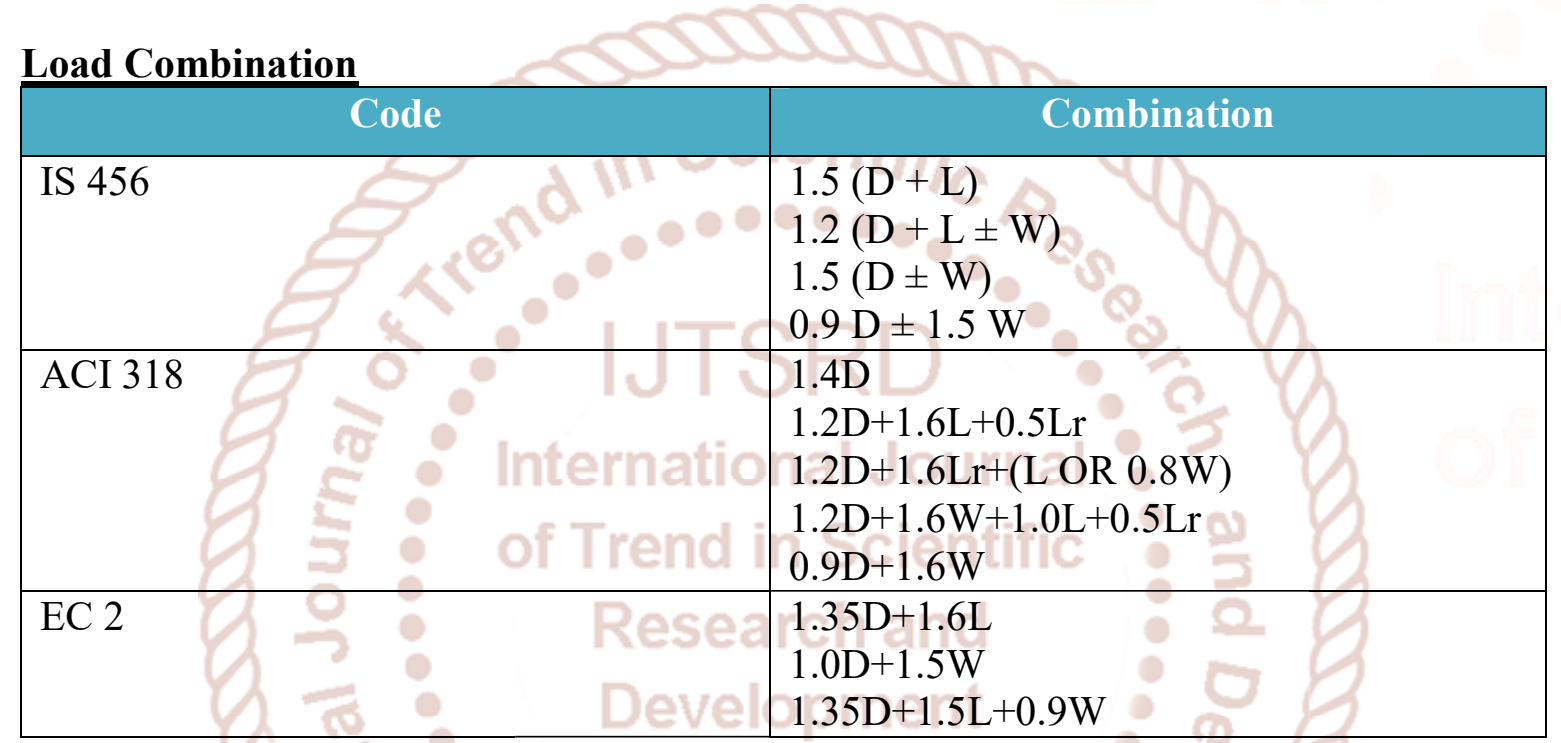

LOAD COMBINATIONS

The load combinations EUROCODE are more as compared to other two codes, this difference makes its impact in design process that is loads come out to be higher than other two, and hence the area of steel.

\section{Beam Parameters of different country codes}

\begin{tabular}{|c|c|c|c|c|}
\hline Parameters & Aci 318 & $E_{1}$ & & IS 456 \\
\hline $\begin{array}{l}\text { L/d } \\
\text { Cantilever } \\
\text { S.S } \\
\text { Continuous }\end{array}$ & $\frac{8}{16}$ & $\begin{array}{l}p=1.5 \% \\
\frac{6}{14} \\
\underline{18}\end{array}$ & $\frac{P=.5 \%}{\frac{8}{16}}$ & $\frac{\frac{7}{20}}{\underline{26}}$ \\
\hline
\end{tabular}

\section{L/d RATIO}

The $\mathrm{L} / \mathrm{d}$ ratio for ACI 318 is modest as compared to other two codes, while EUROCODE has more strict criteria.

\section{Concrete Design Strength Limits}

a. EuroCode II Min=12 Mpa, Max 90Mpa

b. American code Min= 17 Mpa Max no limits

c. Indian std Min $20 \mathrm{Mpa}$ max $80 \mathrm{Mpa}$

The Indian code has neglected higher grade (higher than 80MPA). Which could be incorporated in future. 


\section{STRESS/STRAIN BLOCK PARAMETERS}

a. ACI 318

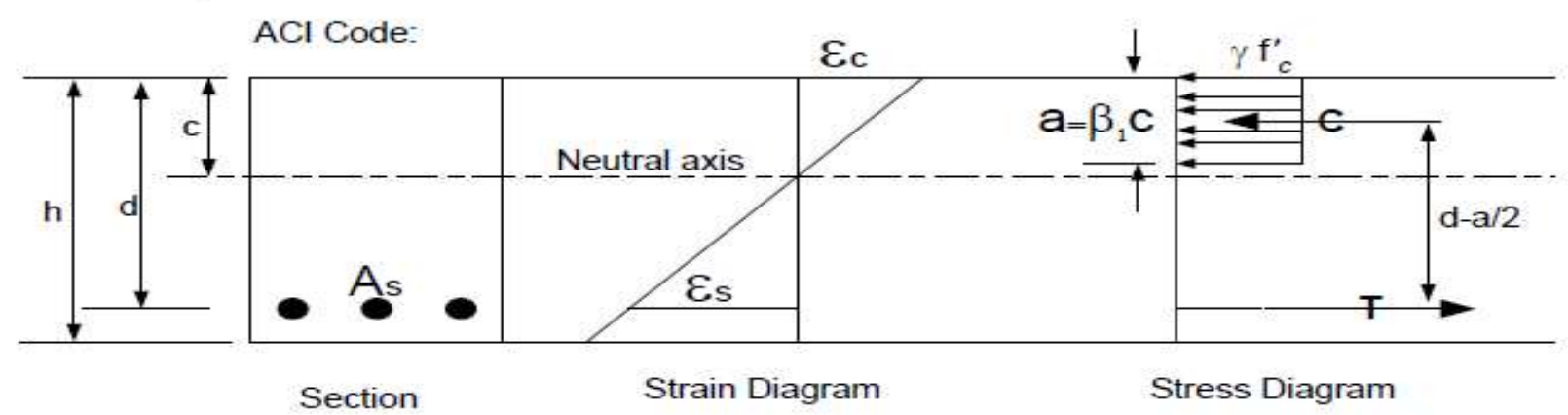

STRESS STRAIN DIAG ACI 318

b. EUROCODE II

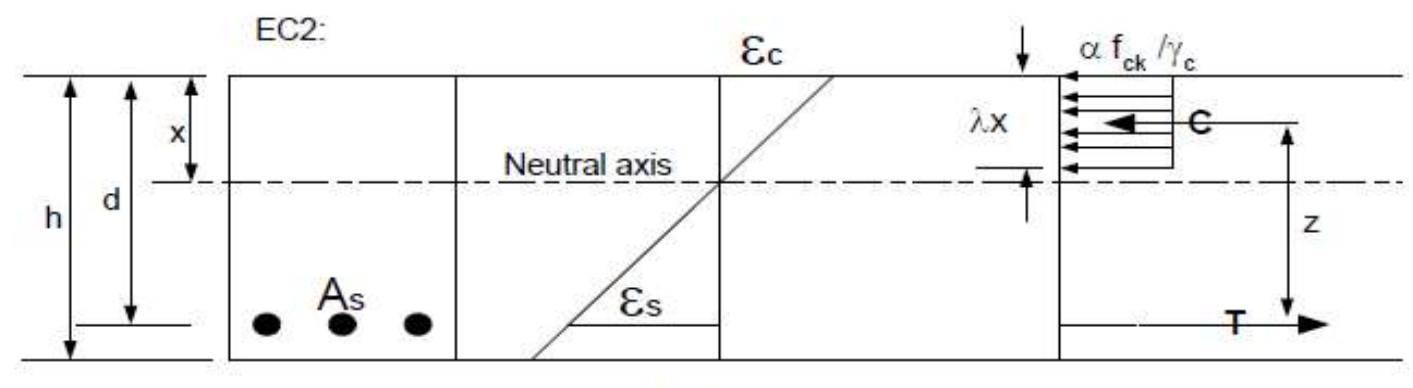

Section

Strain Diagram

Stress Diagram

STRES/STRAIN DIAG. OF EC II

c. IS 4562000

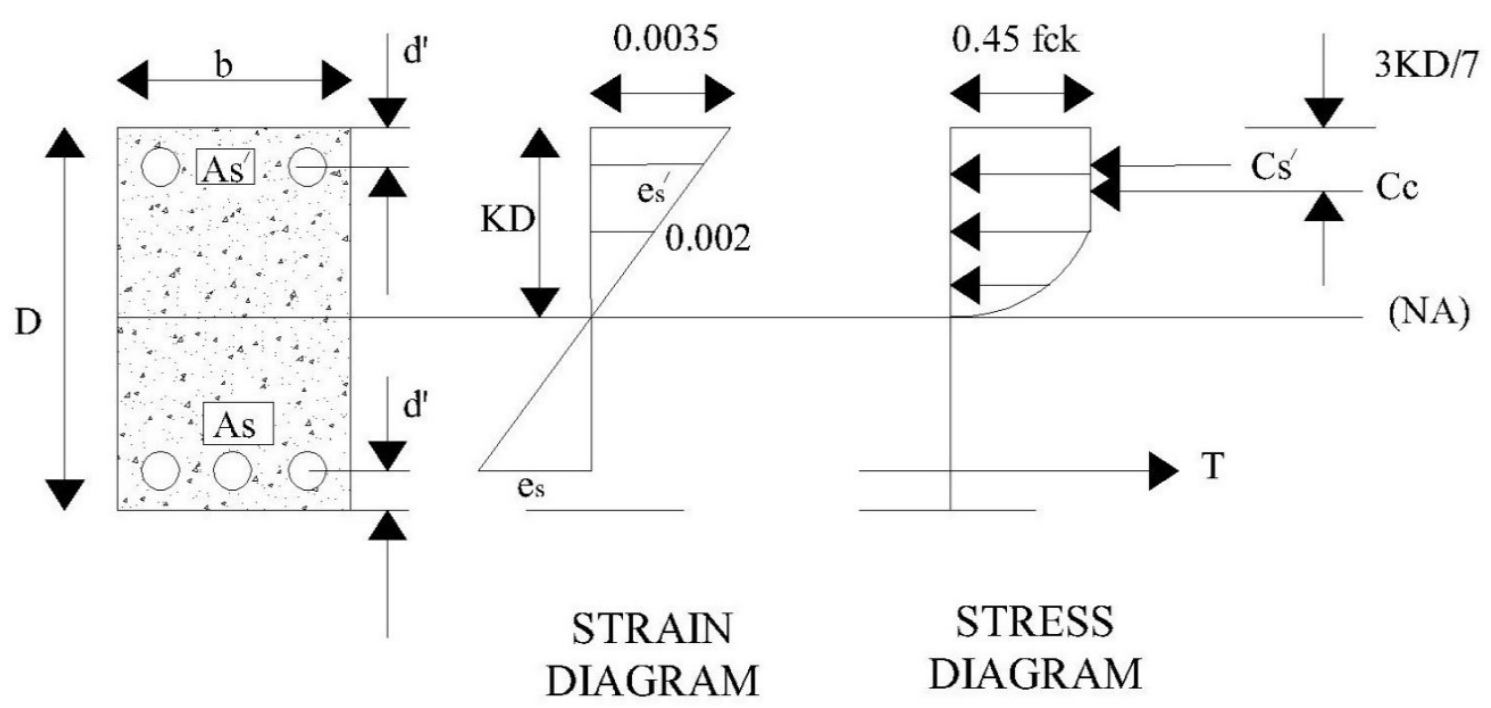

IS 4562000 SRESS/STRAIN

The codes of EC II, ACI 318, don't consider parabolic portion thus this makes the stress block calculation easy also the lever arm calculations. Also the lever arm in EC II, ACI 318 is greater than IS 456, this makes the moment calculation different in all the three codes. 


\section{DESIGN OF DIFFERENT STRUCTURAL MEMBERS}

\section{DESIGN OF SINGLY REINFORCED BEAM}

For the sake of comparison, the parameters required in design process were taken to be same example, Cube compressive strength $(\mathrm{fck}=30)$. $\mathrm{Fy}=500$, dimensions of beam were taken to be same.

Example1 length $=.6 \mathrm{~m}$, Breadth $=230 \mathrm{~mm}$, Depth $=600 \mathrm{~mm}$

Live Load of $40 \mathrm{kn}$

BY ACI 318

Area Of Steel (main reinf.) $=1395 \mathrm{~mm} 2$

By EUROCODE

Area of Steel $=1570.8 \mathrm{~mm} 2$

By IS456

Area of steel $=1341 \mathrm{~mm} 2$

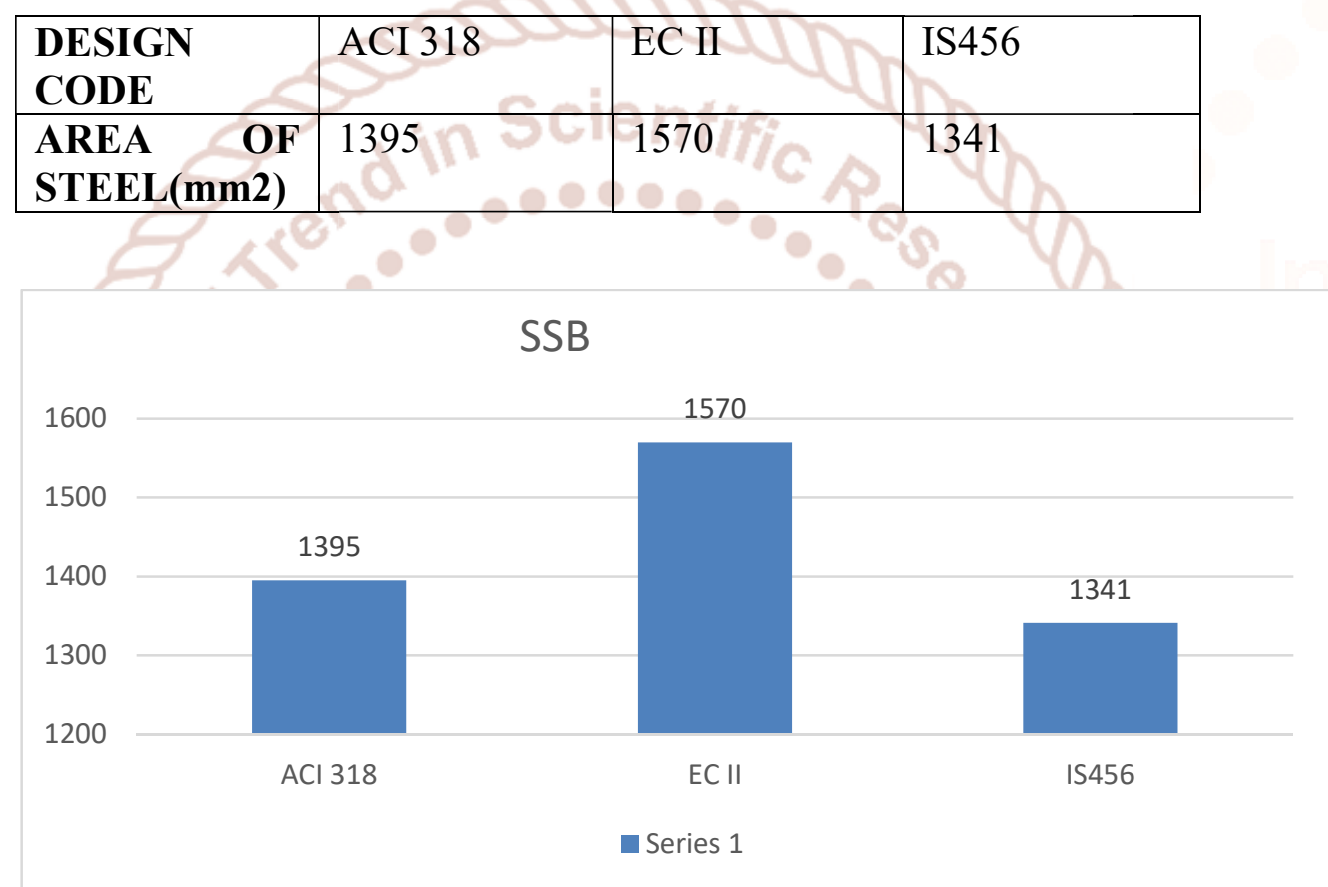

\section{AST FOR SSB}

\section{DOUBLY REINFORCED BEAM}

$\mathrm{LL}=80 \mathrm{KN} / \mathrm{M}, \mathrm{B}=230 \mathrm{D}=450, \mathrm{fck}=30, \mathrm{fy}=500$

\begin{tabular}{|l|l|l|l|}
\hline DESIGN CODE & ACI 18 & EC II & IS456 \\
\hline AST & 1943 & 2154 & 1757 \\
\hline ASC & 496 & 522 & 386 \\
\hline
\end{tabular}

\section{AST FOR D-R BEAM}




\section{FLANGE BEAM DESIGN}

EXAMPLE

Adjacent slab span $=5 \mathrm{~m}$ Beam $690 * 350 \mathrm{~mm}$

$\mathrm{Fck}=30 \mathrm{Mpa} \mathrm{Fyk}=500 \mathrm{Mpa}$

Cover $=45 \mathrm{~mm}$

Live Load $=5 \mathrm{kn} / \mathrm{m} 2$

- BY EC-II

Area of Steel $=2428.86 \mathrm{~mm} 2$

- BY ACI 318

Area of steel $=2122 \mathrm{~mm} 2$

- BY IS456

Area Of Steel $=1964 \mathrm{~mm} 2$

\begin{tabular}{|l|l|l|l|}
\hline DESIGN CODE & ACI 318 SSIN:L4 & EC-II /O & IS456 \\
\hline AREA OF STEEL & 2122 & 2428.66 & 1964 \\
\hline
\end{tabular}

AST OF FLANGE BEAM

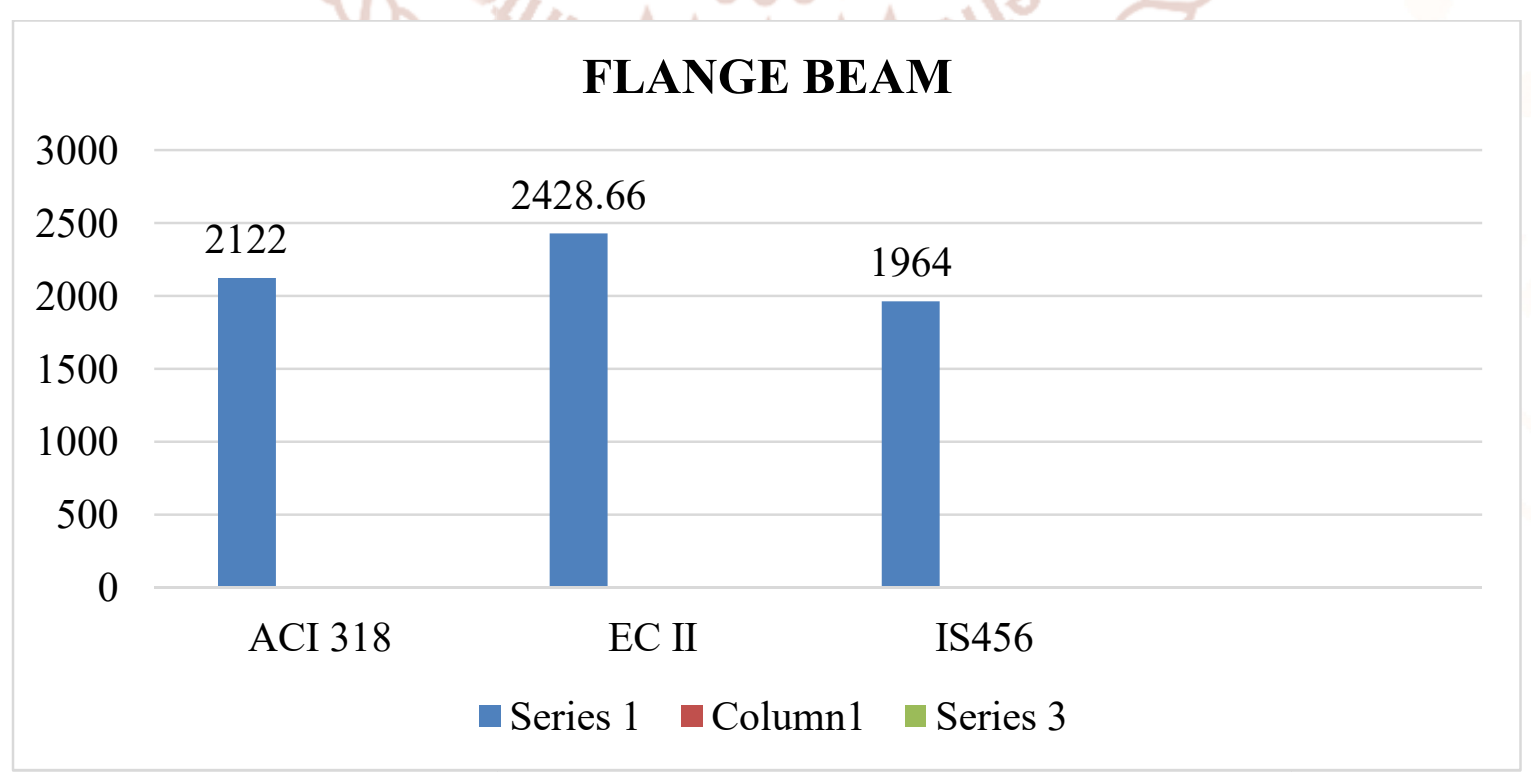

AST OF FLANGE BEAM 
INTERACTION CURVE ACCORDING TO IS 456:2000 ACI 318:11 AND EC II .

- $\quad$ For pt. $=1 \%$

$$
\begin{aligned}
& b=230 \mathrm{~mm} \quad D=525 \mathrm{~mm} \quad \mathrm{~d}^{\prime} / \mathrm{D}=0.1 \quad \mathrm{f}_{\mathrm{ck}}=25 \mathrm{~N} / \mathrm{mm}^{2} \\
& F_{\mathrm{y}}=500 \mathrm{~N} / \mathrm{mm}^{2}
\end{aligned}
$$

\begin{tabular}{|c|c|c|c|c|c|}
\hline \multicolumn{2}{|l|}{ IS } & \multicolumn{2}{|l|}{ ACI } & \multicolumn{2}{|l|}{ EC II } \\
\hline $\begin{array}{l}\mathbf{M}_{\mathrm{U}} / \mathbf{f}_{\mathrm{ck}} \\
\text {.b. } \mathbf{D}^{2}\end{array}$ & $\mathbf{P}_{\mathbf{U}} / \mathbf{f}_{\text {ck. }} \cdot$ b. D & $\begin{array}{l}\mathbf{M}_{\mathrm{U}} / \mathbf{f}_{\mathrm{ck}} \\
. \text { b. } \mathbf{D}^{2}\end{array}$ & $\mathbf{P}_{\mathbf{U}} / \mathbf{f}_{\text {ck }} \cdot$ b. D & $\begin{array}{l}\mathrm{M}_{\mathrm{U}} / \mathrm{f}_{\mathrm{ck}} \\
\text {.b. } \mathrm{D}^{2}\end{array}$ & $\mathbf{P}_{\mathbf{U}} / \mathbf{f}_{\text {ck. }} \cdot$ b. D \\
\hline 0 & .5983 & 0 & .5832 & 0 & 0.6012 \\
\hline .05965 & .4599 & .09854 & .5832 & 0.1071 & 0.5912 \\
\hline .07227 & .4058 & .09778 & .5158 & 0.1104 & 0.5256 \\
\hline .1175 & .1697 & .1105 & .2421 & 0.1307 & 0.2346 \\
\hline .07765 & 0 & .07582 & 0 & .08766 & 0 \\
\hline
\end{tabular}

INTERACTION CHART

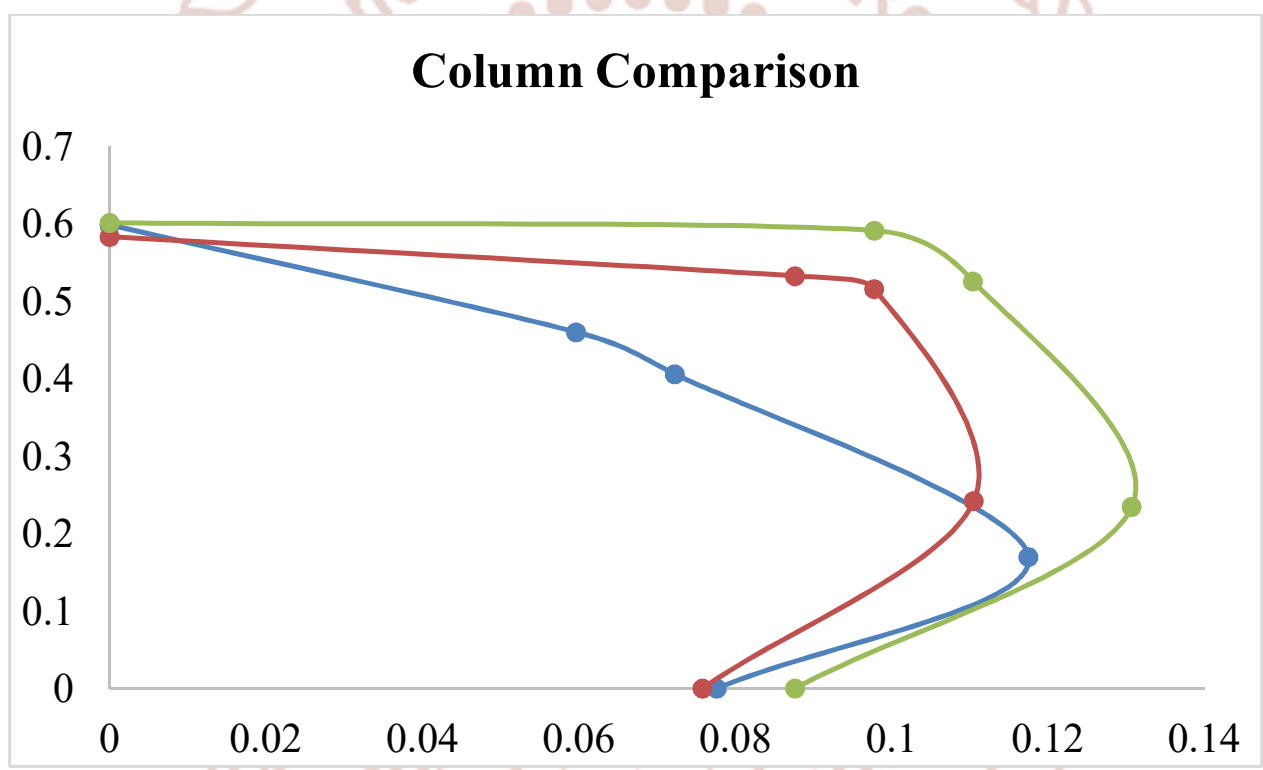

INTERACTION CHART

\section{SLAB DESIGN}

For the sake of comparison design parameters are taken same which are as

fck $=30, \quad$ fy 500 ,

Effective length of slab from center to center of support $=5 \mathrm{~m}$

Live load $=10 \mathrm{kn} / \mathrm{m} 2$, assuming $1 \mathrm{~m}$ stretch for design purposes so $b=1000 \mathrm{~mm}$

\begin{tabular}{|l|l|l|l|}
\hline CODE & IS 456 & EC II & ACI 318 \\
\hline AREA OF STEEL & 851.23 & 765.32 & 734.25 \\
\hline
\end{tabular}

AST OF SLAB 


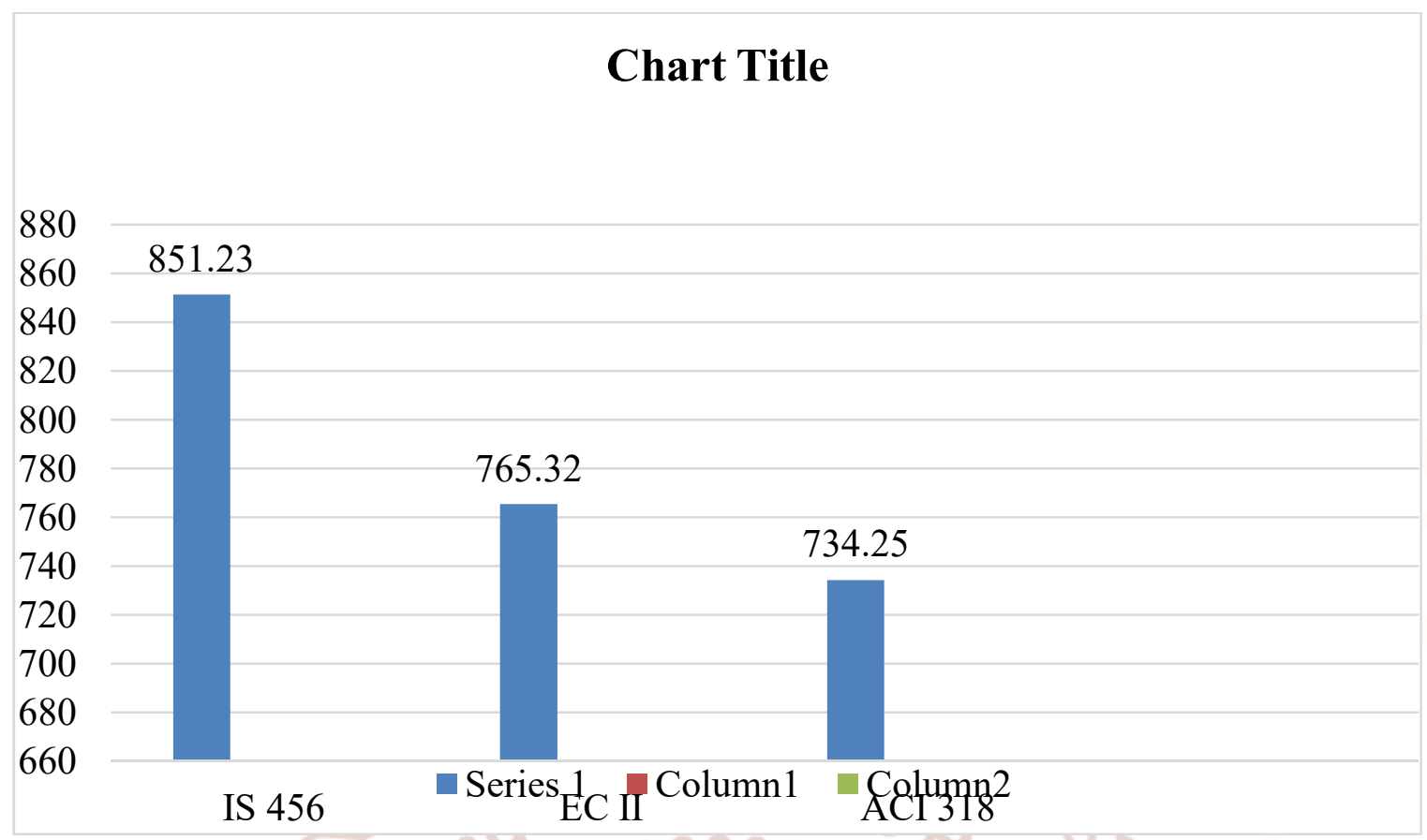

AST OF SLAB

\section{DESIGN OF FOOTING}

EXAMPLE OF A SINGLE SQUARE FOOTING

$\mathrm{fck}=30, \quad \mathrm{fy}=500$,

load coming through column Service live load $=1000 \mathrm{KN}$, Service dead load $=1500 \mathrm{KN}$

Allowable bearing capacity or safe bearing capacity $=250 \mathrm{KN} / \mathrm{m} 2$,

Size of column $400 \mathrm{~mm} * 400 \mathrm{~mm}$

\begin{tabular}{|l|c|c|c|}
\hline CODE & IS 456 IV:24 & EC II & ACI 318 \\
\hline $\begin{array}{l}\text { AREA OF STEEL } \\
\text { (mm2) }\end{array}$ & 4172 & 6298 & 4550 \\
\hline
\end{tabular}

AST OF FOOTING

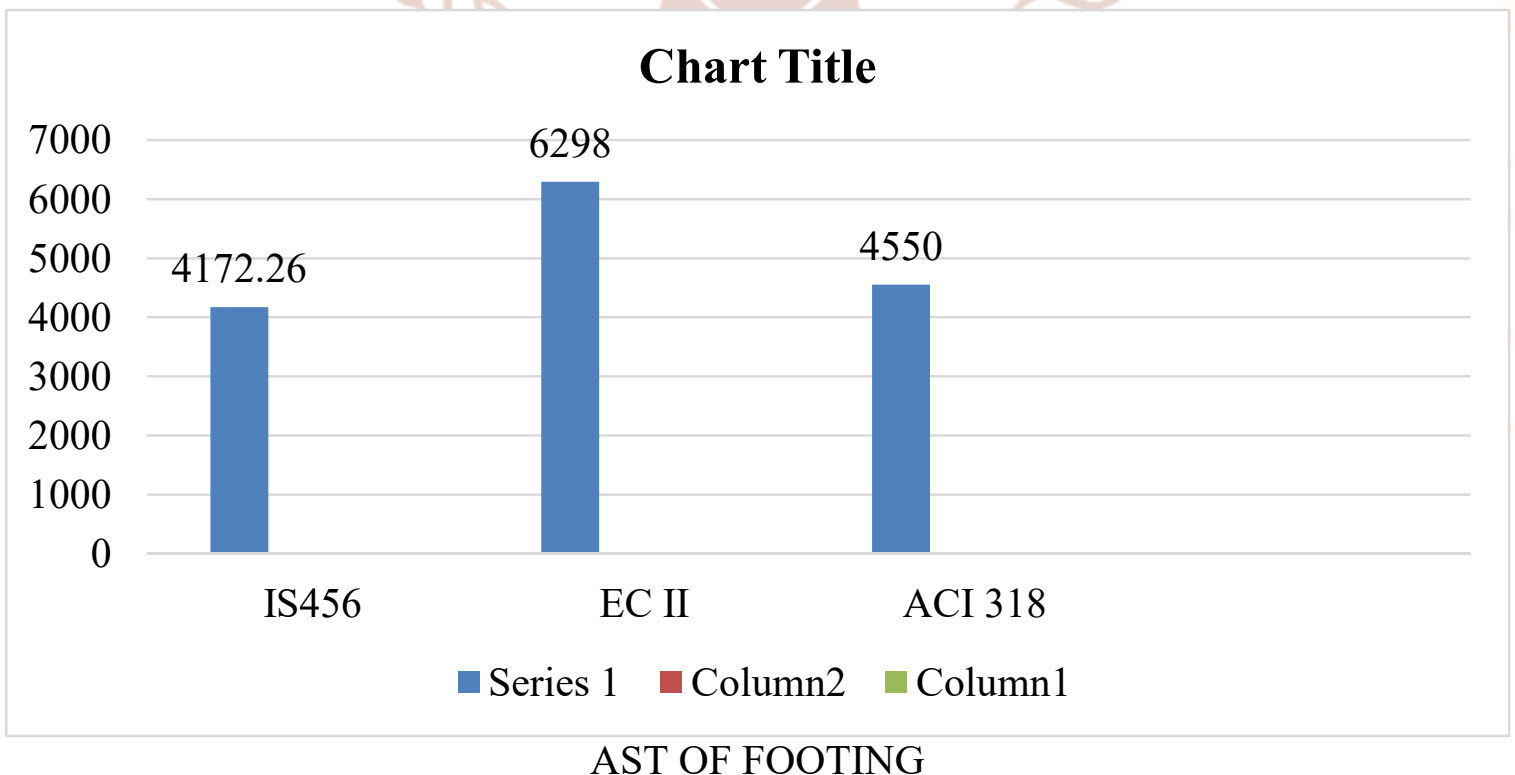




\section{FUTURE SCOPE OF WORK}

The Bearou OF Indian Standards which has developed IS456 2000 has not considered the strain distribution in deep beams which is a major lacuna when it comes in comparison with EUROCODE II or ACI 318, One can develop the strain distribution for IS 456 in line with the other major codes.

In the current times the civil engineering is touching new heights and conquering milestones one after other, the innovation has brought to light new materials which have a great effect on strength, durability, setting time, exothermic heat generation etc of concrete, materials such as add mixtures like plasticizers, water reducing agents retarders etc. Light Weight materials, Geo-Synthetic materials. Their effects are not codified in IS 456, there is a vast field of research in this area. One can test these materials vis a vis concrete and codify the behavior of the same in guided circumstances which will in-turn put into our design code.

IS456 doesn't recognize concrete characteristic strength beyond M80, and this is an area of research one can formulate design criteria for is 456 for concrete strength beyond M80.

\section{REFERENCES}

\section{BOOKS}

1) 1.051 structural engineering design Recitation 5 part 1,design procedures of short columns in accordance to the ACI-318 by Prof. Oral Buyukozturk

2) ACI Design Handbook, "Design of Structural Reinforced Concrete Elements in Accordance with the strength Design Method of ACI 31895,Publication SP-17(97)

3) ENCE 355-Introduction to structural design ,Department of civil and environmental engineering, University of Maryland

4) Jack C. McCormac, James K. Nelson, "Design of Reinforced Concrete ACI 318-11 Code edition" by imcivilengineering.com.

5) N. Krishna Raju, "Design of REINFORCED CONCRETE STRUCTURES", New age international publisher.

6) N. Subramanian, "Design of REINFORCED CONCRETE STRUCTURES”, OXFORD.
7) P. C. Varghese, "Limit State Design Of Reinforced Concrete", PHI learning private limited.

8) S. Ramamrutham, "Design of REINFORCED CONCRETE STRUCTURES", Dhanpatrai publication company.

\section{CODES}

1) ACI Design handbook, "design of structural reinforced concrete elements in accordance with the strength design method of ACI 318 95,Publication SP-17(97).

2) Building code requirement for structural concrete (ACI 318-11) and commentary, reported by ACI committee 318 .

3) Design Aids For Reinforced Concrete to IS : 456 - 1978, "Bureau of Indian standards.(SP -16).

4) Indian standard "Plain and reinforced concreteCode of Practice" (IS 456:2000).

\section{5) EUROCODE II}

\section{WEBSITES}

1) imcivilengineer.com

2) nptel.ac.in

3) www.strunet.com

\section{JOURNALS}

1) https://www.researchgate.net/publication/2641776 04_Comparison_between_ACI_318-

05 and Eurocode_2 EC2-

94 in_flexural_concrete_design

2) IIT Hyderabad Research papers

3) IOSR Journal of Mechanical and Civil Engineering (IOSR-JMCE) e-ISSN: 2278-1684, pISSN: 2320-334X PP 08-12 www.iosrjournals.org

4) International Journal of Scientific and Research Publications, Volume 4, Issue 12, December 2014 1 ISSN 2250-3153 